\title{
Value generators in forestry and logging
}

\author{
Veronika Machová ${ }^{*}$, Jakub Horák ${ }^{2}$ \\ ${ }^{1}$ Institute of Technology and Business, School of Expertness and Valuation, Okružní 517/10, 37001 \\ České Budějovice, Czech Republic \\ ${ }^{2}$ University of Žilina, The Faculty of Operation and Economics of Transport and Communications, \\ Univerzitná 8215/1, 01026 Žilina, Slovakia
}

\begin{abstract}
The aim of business is the company value which depends on its ability to generate future profits. It means that all the future decisions must be $^{1}$ adopted with regard to the influence on the company value. The subject of interest in this paper concerns forestry and logging companies, particularly financial statements of companies that were active on the Czech market in 2016 and thus showed a profit. Aim of this paper is to identify particular value generators of forestry and logging companies in the Czech Republic in 2016. For this reason, the best possible methodology was developed to determine them and the objective was eventually achieved. Using artificial neural networks, a total of 14 indicators, entering a company value creation process most frequently, were identified and measured by the EVA equity indicator. The following key variables were identified as company value generators: external sources, long-term liabilities, material and energy consumption, other operating expenses and sales of goods.

Key words: value generators, financial statements, artificial neural networks, profit
\end{abstract}

\section{Introduction}

Companies must be strong and efficient to be able to exist for a long time because only in such a condition they are able to cope with tough and hard competition, which is the consequence of the globalization of world economy. The desire of every company is to achieve its goals and successfully fulfil its tasks [1].

Brealey, Mayers and Allen [2] claim the company value is a function of benefits which are generated by the company's assets, assets lifetime and the expected pace of growth of future benefits. Nowadays the company value is influenced by several key indicators. One of them is an expected growth [3]. Nenkov [4] states that the aim of business is the company value which depends on its ability to generate future profits. It means that all the future decisions must be adopted with regard to the influence on the company value. It is necessary for a company to concentrate mainly on its position in the market, uniqueness and quality of offered products, innovative abilities of the company employees, effective cost management, ability to effectively use available sources and abilities to search for new investment opportunities [5].

\footnotetext{
*Corresponding author: machova@mail.vstecb.cz
} 
The term of value generator began to appear in academic literature in relation to the concept of shareholder value. Bluszcz and Kijewska [6] maintain that the value generator is a set of several basic economic values which define a company in their summary. The indicator measuring the creation of company value in an annual time horizon is an economic value added EVA [7].

Issham et al. [8] acknowledge that EVA is a useful and significant instrument for the evaluation of company performance and enables to combine such factors as accountancy, economy and market information. Morard and Balu [9] point to the fact that EVA tries to express the real economic company profit. The significant advantage of this indicator is an understandable evaluation of the economic performance of company and the consideration of the degree of investment risks [10]. The economic value added is the most progressive instrument of the measuring of company's performance based on the principle of value management [11].

Linna and Jaakkola [12] claim the methods of the complex evaluation of company are able to record the influence of all the undesirable factors, which influence the whole company. The instruments for the evaluation of company are crucial in all the processes across the whole firm. The evaluation of company is an instrument how to discover the strengths and weaknesses, opportunities and threads and how the company is successful in the market in comparison with its competitors [13].

The industry of forestry involves wood-processing industry, printing and publishing industry, pulp, paper and cardboard industries. At present time the sectors of forestry are becoming significantly more important [14]. Forestry companies of the Czech Republic increasingly depend on the environment. It is possible to claim Czech forestry is characterized by the biological characteristics of production. It means that there is a high dependence on the environmental conditions, long production cycles, time difference between production and relating work processes, demands for large deposits of private production and seasonality. All such factors significantly influence human resources in forestry [15]. Low productivity of this sector is a key factor for the economic backwardness of the Czech Republic. Vnoučková, Urbancová and Smolová [16] admits that the main source of the enhancement of low productivity is mainly the intensification of the activities of the sector. Burivalova, Şekercioğlu and Koh [17] define logging as the processing of woody plants for the production of timber for the purpose of the supplying of world furniture, paper, construction and other markets. However, the consequence of the rise of logging is the tendency to decrease the diversity of species.

It is possible to use bonus and bankruptcy models, economic value added EVA, etc. for the purpose of the measurement of company value. Moreover, it is possible to even use artificial neural networks the inspiration of which is biological neurons [18]. One of their abilities is learning which enables them to even avoid strongly non-linear, hidden dependencies [19]. At presence, artificial neural networks are used in many fields, e.g. agriculture, economy or healthcare, and for various applications. It is obvious that they are used in applications related to the identification of the value generators of companies [20].

Neural networks have been broadly used for the evaluation of companies' performance since 1990's. Joshi and Lam [21] examine the complex prognosis of business, the measurement of performance in particular. They have attempted to model a system of forecast with the help of regressive neural networks and the methods of time series forecasting. Their research deals with the preliminary results of the forecasting of performance in business. The authors state that neural networks are a right instrument for the dealing with such problems. Dameri, Garelli and Resta [22] use neural networks for the analysis of company performance and for the support of the policies of the development of small regions. They focus on the application of unmodified neural network in order to discover the clusters of companies in the micro-regions within urban borders [22]. $\mathrm{Li}$ and $\mathrm{Wu}$ 
[23] argue that not only can the reliable prognosis of commercial performances in the shop with commodities (CVS) help with making a right decision in local circumstances but they can also help with reducing the storage costs and therefore to significantly increase the profit. The main objective of their work was to design a forecasting system based on an extended fuzzy neural network (EFNN) in order to be able to forecast the business performance of CVS. EFNN can provide complex and accurate activating functions and adapt a wider range of non-linear models. The experiments using their methods involving several benchmarking methods have proved that the designed methods have optimal accuracy when they forecast the permanent positive performance of CVS.

\section{Data and Methods}

Data for analysis are included in the Albertina database of Bisnode Czech Republic, a.s. The subject of interest in this paper concerns forestry and logging companies, particularly financial statements of companies that were active on the Czech market in 2016 and thus showed a profit. The data set involves companies classified in the CZ NACE classification of economic activities under Section A: Agriculture, forestry, fishing, Division 02 - Forestry and logging, namely sub-sections 021 - Forestry and other forestry activities and $022-$ Timber harvesting. The examined data set contains records of 316 companies and their complete financial statements (except for annexes). Data from balance sheets, profit and loss statements and cash flow statements will therefore be used. The data will then be put into a table using an Excel spreadsheet. Each row of the table will represent one of the companies that are listed alphabetically. Individual columns contain information from the financial statements.

In the next step, an EVA value will be calculated for shareholders (owners) of each company in a given year of its activities on the market, i.e. an EVA equity parameter.

Firstly, it is necessary to calculate a weighted average cost of capital according to formula No. 1 [24]:

$$
W A C C=r_{f}+r_{L A}+r_{\text {podnikatelské }}+r_{\text {Finstab }}
$$

Where the following applies:

$W A C C=$ Weighted Average Cost of Capital, $r_{f}=$ Risk Free,

$r_{L A}=$ A function of indicators characterizing a company size,

$r_{\text {podnikatelské }}=$ A function of indicators characterizing production performance,

$r_{\text {FinStab }}=\mathrm{A}$ function of indicators characterizing relationships between a company's assets and sources of their coverage.

Then, it is necessary to determine an alternative cost of equity value using formula No. 2 according to Neumaierová and Neumaier [24]:

$$
r_{e}=\frac{W A C C * \frac{U Z}{A}-(1-d) * \frac{U}{B U+O} *\left(\frac{U Z}{A} * \frac{V K}{A}\right)}{\frac{V K}{A}}
$$

Where the following applies:

$r_{e}=$ Rate of Equity,

$W A C C=$ Weighted Average Cost of Capital,

$U Z=$ Remunerated Sources (equity and interest-bearing foreign capital),

$A=$ Assets,

$V K=$ Equity, 
$B U=$ Bank Loans,

$O=$ Bonds,

$\frac{U}{B U+O}=$ Interest Rate, $i$ (Interest) may also be used,

$d=$ Income Tax Rate, $\mathrm{t}$ (Tax) may also be used.

Economic value added for shareholders is derived from a relationship given in formula No. 3 [24]:

Where the following applies:

$$
\text { EVA Equity }=\left(R O E-r_{e}\right) * V K
$$

$R O E=$ Return on Equity.

The set will then be cleared of companies where a problem with the EVA equity calculation arises, which may be caused by unknown or zero values of items necessary for the calculation. The final (resulting) spreadsheet will be imported into the Statistica software, version 12 , to determine a certain extent to which the EVA equity indicator depends on individual items in the financial statements.

Basic data statistics (correlation matrix) will be performed first. Considering a correlation between two variables, their close connection is evident. Identifying these items in the financial statements is necessary for subsequent procedures. Subsequently, tools for automated neural networks using non-linear regression (while assuming at least one hidden layer) will be employed. The EVA equity indicator shall be considered as a dependent variable in the neural networks, but variables will be selected with respect to the business theory of production factors (for more details, see [25]). The data set will then be divided into three individual sets, i.e. training, test and validation. There will be $70 \%$ of input data in the training set, whereas the remaining $30 \%$ will be divided equally into the test set and the validation set, i.e. $15 \%$ of all input data, with neural structures being created with the use of the training data set. To verify reliability of neuronal structures found, the test and validation data sets are used. In total, there will be 10,000 neural networks generated, of which the 5 best performing networks will be preserved. However, the artificial neural networking process may be terminated prematurely if neural networks being created no longer show signs of improvement. Improvement of neural structures is considered to be a state where a particular value of the sum of squares, or their disorder, decreases as the least squares method and entropy will serve as the basis in this respect. Two types of neural networks, MLP (multilayer perceptron neural networks) and RBF (radial basic function neural networks), shall be applied. In relation to hidden and output layers, one will consider all distribution functions that the above software allows, i.e. linear function, logistic function, atanh (hyperbolic tangent) function, exponential function and sine function.

The above will then result in neural structures having abilities to predict the EVA equity based on input data, from which it will be possible to deduce its likely value. The model will only consider variables with real significance for the EVA equity indicator's final value. A neural network that can describe the relationship as correctly as possible will be selected. Such network will have the best performance in the training, test and validation data sets, minimum errors in each data set, and the ability for a clear economic interpretation. Sensitivity analysis shall also be carried out in order to determine which variables enter the calculation while significantly affecting the result. Eventually, value generators of the forestry and logging companies will be identified. 


\section{Results}

Having cleared the input data of companies without the possibility of calculating the EVA equity indicator, financial statements data of 316 forestry and logging companies in the Czech Republic remain for their analysis. Based on the methodology and the found mutual correlation of data and economic interpretation, the following independent variables were determined to enter the calculation: total assets, intangible fixed assets, inventories, longterm receivables, profit / loss of previous years, external sources, long-term liabilities, bank loans and aids, short-term liabilities, sales of goods, material and energy consumption, outputs, other operating expenses and financial result.

Table 1 shows the top five generated and preserved neural networks

Table 1: Preserved neural structures

\begin{tabular}{|l|l|l|l|l|l|l|l|l|l|l|}
\hline $\begin{array}{l}\text { Network } \\
\text { Name }\end{array}$ & $\begin{array}{c}\text { Training } \\
\text { Perform. }\end{array}$ & $\begin{array}{c}\text { Test } \\
\text { Perform. }\end{array}$ & $\begin{array}{l}\text { Validation } \\
\text { Perform. }\end{array}$ & $\begin{array}{c}\text { Training } \\
\text { Error }\end{array}$ & $\begin{array}{c}\text { Test } \\
\text { Error }\end{array}$ & $\begin{array}{c}\text { Validation } \\
\text { Error }\end{array}$ & $\begin{array}{c}\text { Training } \\
\text { Algorithm }\end{array}$ & $\begin{array}{c}\text { Error } \\
\text { Function }\end{array}$ & $\begin{array}{c}\text { Hidden } \\
\text { Layer } \\
\text { Activation }\end{array}$ & $\begin{array}{c}\text { Output } \\
\text { Activation } \\
\text { Function }\end{array}$ \\
\hline $\begin{array}{l}\text { MLP } \\
14-26-1\end{array}$ & 0.983301 & 0.651976 & 0.940207 & 9250127 & 2965921 & 17553151 & BFGS 50 & $\begin{array}{l}\text { Sum of } \\
\text { squares }\end{array}$ & $\begin{array}{l}\text { Hyperbolic } \\
\text { tangent }\end{array}$ & $\begin{array}{l}\text { Hyperbolic } \\
\text { tangent }\end{array}$ \\
\hline $\begin{array}{l}\text { MLP } \\
14-7-1\end{array}$ & 0.986775 & 0.805951 & 0.946692 & 7337913 & 1158857 & 5330874 & BFGS 102 & $\begin{array}{l}\text { Sum of } \\
\text { squares }\end{array}$ & Logistic & Logistic \\
\hline $\begin{array}{l}\text { MLP } \\
14-6-1\end{array}$ & 0.988330 & 0.810602 & 0.954352 & 6480130 & 2376759 & 6183490 & BFGS 78 & $\begin{array}{l}\text { Sum of } \\
\text { squares }\end{array}$ & $\begin{array}{l}\text { Hyperbolic } \\
\text { tangent }\end{array}$ & Logistic \\
\hline $\begin{array}{l}\text { MLP } \\
14-6-1\end{array}$ & 0.982432 & 0.519603 & 0.945845 & 9895705 & 2194911 & 5692542 & BFGS 49 & $\begin{array}{l}\text { Sum of } \\
\text { squares }\end{array}$ & Logistic & Identity \\
\hline $\begin{array}{l}\text { MLP } \\
14-6-1\end{array}$ & 0.981778 & 0.727762 & 0.946615 & 10200325 & 1248142 & 6144683 & BFGS 54 & $\begin{array}{l}\text { Sum of } \\
\text { squares }\end{array}$ & Logistic & Identity \\
\hline
\end{tabular}

Source: Authors.

The table clearly shows that all 5 preserved neural networks are of the MLP type, so the best characteristics are assumed here. The training algorithm included different QuasiNewton variants in each case. The least squares method was determined as an error function for each of the preserved networks. In three cases, hidden layers of neurons were activated by the logistic function, and as for the other two, the hyperbolic tangent was the hidden layer activation function. The output activation function coincided with the activation function only in two cases - twice the logistic function and the identity function, and once the hyperbolic tangent function. In the first layer of all preserved neural networks, there is the same number of neurons, i.e. 14. In the third to the fifth preserved neural networks, there is also the same number of hidden layers, i.e. 6 .

Table 2 shows relevance of the networks generated.

Table 2: Performance of generated networks

\begin{tabular}{|l|c|l|r|}
\hline Neural Network & Training & Test & \multicolumn{1}{|c|}{ Validation } \\
\hline MLP 14-26-1 & 0.983301 & 0.651976 & 0.940207 \\
\hline MLP 14-7-1 & 0.986775 & 0.805951 & 0.946692 \\
\hline MLP 14-6-1 & 0.988330 & 0.810602 & 0.954352 \\
\hline MLP 14-6-1 & 0.982432 & 0.519603 & 0.945845 \\
\hline MLP 14-6-1 & 0.981778 & 0.727762 & 0.946615 \\
\hline
\end{tabular}

Source: Authors.

Regarding the table above, performance of the data sets in the preserved networks may be compared, where it follows that the higher the performance value is (i.e. the correlation coefficient), the better, with a value of 1.00 representing $100 \%$ performance. In the best possible manner, the values should be at their highest or the same in all three data sets [26]. It may be seen that MLP 14-6-1 achieves the highest performance and is also one of the 
preserved networks with the least number of hidden layers. The test data set also shows lower values in all preserved neural networks in comparison with the training and validation sets whose data group performance is of a very good standard in all preserved networks.

In order to better estimate the correct result, Table 3 gives parameters of predictions made using the individual networks.

Table 3: Parameters of predictions

\begin{tabular}{|l|r|r|r|r|r|}
\hline Prediction Parameter & 1. MLP & 2. MLP & 3. MLP & 4. MLP & 5.MLP \\
& $14-26-1$ & $14-7-1$ & $14-6-1$ & $14-6-1$ & $14-6-1$ \\
\hline Minimum predictions (Training) & -54976.2 & -51168.9 & -50011.8 & -45851.6 & -45985.0 \\
\hline Maximum predictions (Training) & 336735.3 & 336815.3 & 336806.5 & 326929.8 & 329309.7 \\
\hline Minimum predictions (Test) & -17787.8 & -14718.8 & -22380.4 & -8574.2 & -11077.9 \\
\hline Maximum predictions (Test) & 11845.0 & 5832.6 & 5165.3 & 9894.7 & 6933.4 \\
\hline Minimum predictions (Validation) & -94052.6 & -51359.0 & -50346.1 & -67637.4 & -49941.0 \\
\hline Maximum predictions (Validation) & 8527.9 & 18913.4 & 7802.9 & 8957.1 & 7261.0 \\
\hline Minimum residuals (Training) & -23745.1 & -24830.4 & -21073.2 & -27310.1 & -25763.3 \\
\hline Maximum residuals (Training) & 20387.5 & 14329.2 & 16071.0 & 17147.8 & 16440.1 \\
\hline Minimum residuals (Test) & -10263.1 & -4793.6 & -3822.5 & -9522.3 & -7198.4 \\
\hline Maximum residuals (Test) & 8355.2 & 5286.2 & 12947.8 & 4006.9 & 2900.5 \\
\hline Minimum residuals (Validation) & -8400.4 & -9390.8 & -10403.7 & -9208.3 & -10808.7 \\
\hline Maximum residuals (Validation) & 33302.9 & 11365.1 & 12315.5 & 10489.0 & 12185.2 \\
\hline Minimum standard residuals (Training) & -7.8 & -9.2 & -8.3 & -8.7 & -8.1 \\
\hline Maximum standard residuals(Training) & 6.7 & 5.3 & 6.3 & 5.5 & 5.1 \\
\hline Minimum standard residuals (Test) & -6.0 & -4.5 & -2.5 & -6.4 & -6.4 \\
\hline Maximum standard residuals (Test) & 4.9 & 4.9 & 8.4 & 2.7 & 2.6 \\
\hline Minimum standard residuals (Validation) & -2.0 & -4.1 & -4.2 & -3.9 & -4.4 \\
\hline Maximum standard residuals (Validation) & 7.9 & 4.9 & 5.0 & 4.4 & 4.9 \\
\hline
\end{tabular}

Source: Authors.

It is apparent from Table 3 that the second and the third preserved neural networks have the most similar results between the minimum values of the training and the validation data group predictions. In the training and the test data sets, the two networks also have very similar maximum values and very low minimum standard residual values. In the validation data group, however, the two networks are almost identical, both in the minimum and the maximum values.

Finally, sensitivity analysis was conducted to identify value generators affecting the paper's industry of interest. The analysis is summarized in Table 4. 
Table 4: Sensitivity Analysis

\begin{tabular}{|c|c|c|c|c|c|c|}
\hline Indicator & $\begin{array}{l}\text { 1.MLP } \\
14-26-1\end{array}$ & $\begin{array}{l}\text { 2.MLP } \\
14-7-1\end{array}$ & $\begin{array}{l}3 . M L P \\
14-6-1\end{array}$ & $\begin{array}{l}\text { 4.MLP } \\
14-6-1\end{array}$ & $\begin{array}{l}5 . M L P \\
14-6-1\end{array}$ & Average \\
\hline External sources & 5.13075 & 1.56081 & 4.43047 & 72.29672 & 82.27947 & 33.13965 \\
\hline Long-term liabilities & 15.78779 & 23.33231 & 25.29810 & 37.55004 & 26.79865 & 75338 \\
\hline Material a & 1.33732 & 2.42928 & \begin{tabular}{|l|}
62.03859 \\
\end{tabular} & 2.06980 & \begin{tabular}{|l|}
1.95573 \\
\end{tabular} & 5614 \\
\hline Other ope & 1.75454 & 3.71286 & 45.21382 & 1.43566 & 1.23112 & 10.66960 \\
\hline Sales of gc & 1.18108 & 3.03160 & 37.32229 & 2.28484 & 2.26545 & 1705 \\
\hline Short & 2.27391 & 6.11197 & 17.78270 & 9.09170 & 7.10810 & 8.47368 \\
\hline Finan & 27.15702 & 1.94822 & 4.88490 & 3.47984 & 2.43826 & 7.98165 \\
\hline Out & 1.322852 & 2.435458 & 2.664672 & 5.572817 & \begin{tabular}{|l|}
9.468574 \\
\end{tabular} & 4.292875 \\
\hline Inve & 2.895362 & 3.023984 & 1.675177 & 3.437309 & 3.246568 & 5680 \\
\hline Long-term & 1.022961 & 1.047101 & 1.085227 & 4.296865 & 6.120598 & 4550 \\
\hline Profit / Lo & 6.183940 & 1.839675 & 2.100683 & 1.163658 & 1.415109 & 2.540613 \\
\hline & 1.501360 & 1.066261 & 3.978169 & 3.034107 & 2.565586 & 2.429096 \\
\hline & 1.301109 & 1.435446 & 2.466732 & 3.897952 & \begin{tabular}{|l|}
1.635627 \\
\end{tabular} & 2.147373 \\
\hline Intangible fixed assets & 1.003957 & 1.023130 & 1.056619 & 1.478891 & 2.925599 & 1.497640 \\
\hline
\end{tabular}

Source: Authors.

Even without a more careful examination of the above sensitivity analysis table, it is obvious that in the fourth and the fifth preserved networks, External resources are of the highest importance with high significance indices. Long-term liabilities of the above companies also reach high values in all preserved networks. Interestingly, the last three networks with at least one indicator value greater than 25 are also networks with the same as well as lowest number of hidden layers (6). In the first neural network, Financial result and Long-term liabilities are the most important generators of company values (MLP 14-7-1). The same applies to Material and energy consumption in the third network (3. MLP 14-6-1) and External sources in the fourth and the fifth network (4. and 5. MLP 14-6-1). The remaining selected items also play a significant but not so fundamentally influencing role in creating company values.

\section{Conclusion}

The paper's objective was to identify particular value generators of forestry and logging companies in the Czech Republic in 2016. For this reason, the best possible methodology was developed to determine them and the objective was eventually achieved. Using artificial neural networks, a total of 14 indicators, entering a company value creation process most frequently, were identified and measured by the EVA equity indicator. The following key variables were identified as company value generators: external sources, long-term liabilities, material and energy consumption, other operating expenses and sales of goods. Thus, forestry and logging companies operating in the Czech Republic should primarily focus on the previously mentioned items of financial statement. However, other, though not so important, value generators, whose ranking of importance is shown in Table 4, should not be neglected. The results presented have great potential and it is appropriate to follow them up with further research. As part of a new trend related to the increasing popularity of the EVA equity indicator, it would therefore be advisable to determine what impact the above variables have on the indicator and what their relationship is to it. Another possible course of action may reside in decomposition of partial indicators and their incorporation into operational and tactical goals of the companies, since, as may be argued, all businesses worldwide have one common objective, i.e. creating values for business shareholders (owners). 


\section{Acknowledgements}

This article was supported by the project "Stabilization and development of SME in rural areas", reg. No. TL01000349, the TACR Éta programme.

\section{References}

1. T. Klieštik, M. Mišánková, K. Valášková, L. Švábová, Bankruptcy prevention: New effort to reflect on legal and social changes. Science and Engineering Ethics, 24(2), 791-803 (2018)

2. R.A. Brealey, S.C. Myers, F. Allen, Principles of corporate finance. $10^{\text {th }}$ ed., 914 p. (2013)

3. J. Vrbka, Z. Rowland, Assessing the financial health of companies engaged in mining and extraction using methods of complex evaluation of enterprises. Contributions to Economics, 321-333 (2019)

4. D. Nenkov, Growth policy and value creation in companies. Ikonomicheski Izsledvania, 25(4), 36-65 (2016)

5. J. Klieštiková, M. Mišánková, T. Klieštik, Bankruptcy in Slovakia: International comparison of the creditor's position. Oeconomia Copernicana, 8(2), 221-237 (2017)

6. A. Bluszcz, A. Kijewska, A. Sojda, Economic value added in metallurgy and mining sector in Poland. Metalurgija, 54(2), 437-440 (2015)

7. J. Vrbka, Modeling the future development of top company indicator EVA equity using indicator breakdown and sensitivity analysis on an example of a specific company. Proceedings of the $5^{\text {th }}$ International Conference Innovation Management, Entrepreneurship and Sustainability (IMES2017), pp. 1095-1106 (2017)

8. I. Issham, A.S.M. Fazilah, Y.S. Hwa, A.A. Kamil, Economic value added (EVA) as a performance measurement for GLCs vs Non-GLCs: Evidence in Bursa Malaysia. Prague Economic Papers, 17(2), 168-179 (2008)

9. B. Morard, F.O. Balu, Developing a practical model for calculating the economic value added. Economic Computation and Economic Cybernetic Studies and Research, 43(3), 107-122 (2009)

10. V. Stehel, M. Vochozka, The Analysis of the Economical Value Added in Transport. Nase More, 63(3), 185-188 (2016)

11. B. Kollar, T. Klieštik, Simulation approach in credit risk models. 4th International Conference on Applied Social Science. Information Engineering Research Institute, Advances in Education Research, 51, 150-155 (2014)

12. P. Linna, H. Jaakkola, Toward Finding Culture Assessment Tools for SE Companies. PICMET 2010: Technology Management for Global Economic Growth (2010)

13. M. Vochozka, Z. Rowland, J. Vrbka, Financial analysis of an average transport company in the Czech Republic. Nase More, 63(3), 227-236 (2016)

14. M. Dieter, C. Thoroe, Forestry and forest industry sector in the Federal Republic of Germany according to the new European-Wide sector definition.

Forstwissenschaftiches Centralblatt, 122(2), 138-151 (2003)

15. M. Levá, H. Čermáková, H. Vostrovská, M. Stárová, The Profitability Assessment of Selected Companies Providing Services to Forestry in the Czech Republic. Reports of Forestry Research-Zpravy lesnickeho vyzkumu, 61(2), 145-150 (2016) 
16. L. Vnoučková, H. Urbancová, H. Smolová, Strategic talent management in agricultural and forestry companies. Agricultural Economics (Zemědělská ekonomika), 62(8), 345355 (2016)

17. Z. Burivalova, Ç.H. Şekercioğlu, L.P. Koh, Thresholds of Logging Intensity to Maintain Tropical Forest Biodiversity. Current Biology, 24(16), 1893-1898 (2014)

18. M.S. Hossain, Z.CH. Ong, Z. Ismail, S. Noroozi, S.Y. Khoo, Artificial neural networks for vibration based inverse parametric identifications: A review. Applied Soft Computing, 52, 203-219 (2017)

19. J. Vrbka, Z. Rowland. Stock price development forecasting using neural networks. SHS Web of Conferences: Innovative Economic Symposium 2017 - Strategic Partnership in International Trade, 39 (2017)

20. P. Horváthová, Methodology of Introduction and Utilization of Talent Management in the Organization. Littera Scripta, 6(2), 35-46 (2013)

21. A. Joshi, S.S.Y. Lam, Business performance prediction using recurrent neural networks. IIE Annual Conference and Exhibition, pp. 1-6 (2006)

22. R.P. Dameri, R. Garelli, M. Resta, Unsupervised Neural Networks for the Analysis of Business Performance at Infra-City Level. Organizational Innovation and Change, 203-215 (2016)

23. S.G. Li, Z.M. Wu, Business performance forecasting of convenience store based on enhanced fuzzy neural network. Neural Computing and Applications, 17(5-6), 569-578 (2008)

24. I. Neumaierová, I. Neumaier, Finanční analýza průmyslu a stavebnictví za rok 2007 [Financial analysis of industry and construction for the year 2007]. Analyzy MPO [Analyzes of MIT], 187 p. (2008)

25. G. Wöhe, E. Kislingerová, Úvod do podnikového hospodářství [Introduction to business economy]. $2^{\text {nd }}$ ed. Prague: C.H. Beck, 928 p. (2007)

26. J. Vrbka, Z. Rowland, P. Šuleř, Comparison of neural networks and regression time series in estimating the development of the EU and the PRC trade balance. SHS Web of Conferences: Innovative Economic Symposium 2018 - Milestones and Trends of World Economy, 61 (2019) 